\title{
COMPETITIVE STRATEGY, MAS INFORMATION AND ORGANIZATIONAL PERFORMANCE: EVIDENCE FROM A DEVELOPING ECONOMY
}

\author{
Lokman Mia, Griffith University, Brisbane, Queensland, Australia \\ Sirilak Bangchokdee, Prince of Sonkla University, Thailand
}

\begin{abstract}
This study examines the role of managerial use of MAS information in the relationship between organizations' competitive strategy and performance. In total, 108 General Managers (GMs) from medium to large manufacturing organizations participated in the study. Partial least square (PLS) method was used to analyse the data. The results reveal that competitive strategy was positively associated with the organizations' financial performance both directly and indirectly via managerial use of the MAS information. In other words, the use of the MAS information plays a significant role in facilitating the positive influence of an organization's competitive strategy on its financial performance.
\end{abstract}

Keywords: Competitive Strategy, MAS Information, Organizational Performance

\section{INTRODUCTION}

Previous research emphasises importance of understanding the relationship between strategy and accounting control systems (Chenhall and Langfield-Smith, 1998; Chong and Chong, 1997; Dent, 1990; Otley, 1980; Simons, 1987, 1990). Simons (1987) suggests that understanding the relationship is a prerequisite to the development of general theories about accounting control systems in organizations. Chenhall and Langfield-Smith (1998) argue that to achieve competitive advantage and high performance, an organization's strategy ought to be supported by necessary information provided by MAS (hereafter MAS information). MAS (management accounting system) is considered as a subsystem of the accounting control system in an organization (Chong and Chong, 1997; Otley, 1980). This study argues that it is critical to understand the role of managerial use of the MAS information in the relationship between strategy and performance as such understanding will help organizations in designing appropriate MAS to provide necessary information to support their strategy in achieving competitive advantage and attain high performance.

To date, few studies have examined the relationship between competitive strategy and the use of MAS information. However, the findings of these studies are mixed (see, for instance, (Abernethy and Guthrie, 1994; Chong and Chong, 1997). We contend that a potential reason for the mixed results is that the strategy variable in these studies was defined using Miles and Snow's (1978) typology, which has been criticised as having too broad an intention and as lacking in precisely describing behaviour (Abernethy and Lillis, 1998; Langfield-Smith, 1997). Strategy explained following Miles and Snow's (1978) typology may thus not be able to indicate the specific extent of the use of the MAS information under a particular strategy (see Dermer, 1977; Otley and Barry, 1980). For example, companies with a defender strategy (hereafter, defenders), one of Miles and Snow's (1978) strategy typology, are likely to have too broad (ambiguous) intention. Defenders which normally have a narrow range of products are able to compete either through reducing costs or continuously improving quality of existing products (Kald et al., 2000; Olson and Slater, 2002). Defenders focusing on cost reduction may require more financial information for monitoring manufacturing costs, but they may not use much broad scope MAS information. However, defenders focusing on improving product attributes such as quality may require more broad scope MAS information relating to product quality including reliability and performance. Thus, companies with a defender strategy (as per Miles and Snow's typology), may require either high or low broad scope MAS information. This means strategy variable operationalised following Miles and Snow's (1978) typology may not be related to the use of particular information type such as broad scope MAS information.

Porter's typology, on the other hand, has been accepted as having a specific intention, as it indicates precisely how an organization competes with rivals within its industry (Kald, Nilsson, and Rapp, 2000; Langfield-Smith, 1997). Dermer (1977) and Otley and Berry (1980) point out that organizations require specific objectives (intentions) in order to design specific and effective organizational control systems. We view competitive strategy based on Porter's typology (having specific intention) is able to more specifically indicate usage of broad scope MAS information. This relationship warrants further study.

Because of deregulation, change in product and process technologies, electronic communication and ever changing customer tastes and preferences (Mia and Clarke, 1999; Patiar, 2005), to day's business environment is global and fiercely competitive, therefore uncertain. The relevant literature suggests that to cope with the uncertain environment, managers require more broad 
scope MAS information (Chenhall and Morris, 1986; Gordon and Narayanan, 1984). Broad scope MAS information, including historical, financial, external, internal, non-financial and future-oriented information (Chenhall and Morris, 1986), can help managers to better understand uncertain situations, as it focuses on information relating to the sources of the uncertainty. Thus, it can help managers make appropriate decisions in response to the uncertainty. For example, using the information, managers can continuously monitor and identify customer needs and competitors' product attributes (Mia and Clarke, 1999). This enables them to determine the right product attributes to meet the changing needs of customers and so become more competitive than other companies (Mia and Clarke, 1999). Accordingly, the company's performance may improve.

Although previous researchers have looked into the relationships between (a) contextual variables like environmental uncertainty and the use of broad scope MAS information (Patiar, 2005; Chenhall and Morris, 1986; Gordon, 1984) and (b) the use of broad scope MAS information and organizational performance (Chong and Chong, 1997; Mia, 2000), there is a dearth of such research on how the competitive strategy is related to the use of broad scope MAS information and how the use of such information is related to organizational performance. This study contributes towards a better understanding of the above relationships.

\section{THEORY AND HYPOTHESES}

\subsection{Competitive strategy and financial performance}

An organization's financial performance relates to how well the organization achieves its financial objectives in terms of profitability, sales revenue and utilisation of assets (Kaplan and Norton, 1996). Financial performance can be assessed using measures such as sales growth, operating income and ROI (Hoque and James, 2000; Dess and Davis, 1984; Mosakowski, 1993). The extant literature suggests that companies employing a cost leadership strategy only or a differentiation strategy only are unlikely to gain superior performance in today's competitive environment (Helms, Dibrell, and Wright, 1997; Perera, Harrison, and Poole, 1997; Yamin, et al, 1999). Rather, the companies need to employ a combination of both strategies to be successful in their industry (Dess and Davis, 1984; Helms et al., 1997; Yamin et al., 1999). Following the literature, the present study conceptualises competitive strategy as the extent to which a company employs Porter's $(1980,1985)$ typology of a differentiation strategy, rather than categorising the strategy into "a cost leadership strategy" or "a differentiation strategy". Companies employing a cost leadership strategy seek to become a lowestcost producer in its industry, normally by offering standard or no-frill products to customers. "Low-cost producers typically sell standard, or no-frills, products and place considerable emphasis on reaping scale or absolute cost advantages from all sources" (Porter, 1985, p. 13). By selling products at, or lower than, competitive prices, cost leaders can achieve higher returns by producing products at lower cost (Porter, 1985). On the other hand, a company employing a differentiation strategy provides products with unique attributes that meet customer needs and/or that represent superior value to customers. These attributes include product quality, flexibility, image, and features; delivery systems; market approaches; after sales services; and brand image that are superior to competitors' products (Porter, 1980). Companies offering the unique products are able to gain customer loyalty and sell products at premium price, which in turn may increase their return. If such unique products satisfy customers, they may become repeat purchasers and be willing to pay premium price (Tsiotsou, 2006). Companies employing more of a differentiation (that is less of a cost leadership) strategy continuously improve or create superior products for customers and attempt to differentiate their products from those of their competitors. However, they are likely to place relatively less attention on cost reduction as their emphasis is on creation of superior products and or differentiated products. On the other hand, companies employing relatively less of a differentiation (that is more of a cost leadership) strategy focus more on cost reductions by having a tight cost control and minimizing costs of R\&D, marketing and service. They are more likely to provide standard products to customers.

The extant literature suggests that companies employing a differentiation strategy can achieve higher financial performance over time as they can obtain a higher profit margin. This is because such companies are rewarded for their product uniqueness (Dess and Davis, 1984; Porter, 1980). Customers are normally willing to pay more for uniqueness of products (Reitsperger et al., 1993). Louis Vuitton, for instance, can sell handbags at a premium price because of the perceived high quality of the product, good customer service and unique design. The price of the Louis Vuitton handbag "Monogram Multicolore Ursula" is around \$US 1,950 (eLuxury, 2007). Mercedes, another example, is able to set premium prices for its cars as the customers perceive that Mercedes vehicles mean high performance, safety and prestige (Kotler, 2003). Prior studies found that a company providing high quality products can achieve high customer satisfaction (Anderson, Fornell, and Lehmann, 1994; Anderson and Sullivan, 1993; Carmeli and Tishler, 2005; Tsiotsou, 2006). Increased 
customer satisfaction can help companies to reduce marketing costs: "word of mouth from satisfied customers can reduce the cost of attracting new customers and can have the exact opposite effect with dissatisfied customers" (Devaraj, et al, 2001, p. 435). Companies employing a differentiation strategy are able to gain a large sales volume, resulted from a large market share. The uniqueness of the products can help such companies sustain the current customer loyalty (Porter, 1980) and attract potential customers to trial the products (see, Sands, 2006;; Hambrick, 1983).

Summarising the discussion above, we contend that companies focusing more on a differentiation strategy tend to gain higher profit margins because they can price their products at premium prices, reduce production and marketing costs due to employees' learning experiences, and high sales volume resulted from a large market share. Therefore, the following hypothesis is proposed.

Hypothesis 1: The more a company employs a differentiation strategy, the greater is its financial performance

\subsection{Competitive strategy and managerial use of broad scope MAS information.}

Many researchers have pointed out the importance of understanding the relationship between strategy and the usefulness of MAS information (Chenhall and Langfield-Smith, 1998; Chong and Chong, 1997; Dent, 1990; Otley, 1980; Simons, 1987, 1990). Simons (1987) suggests that an understanding of the relationship is important as it is a prerequisite to the development of theories about control systems in organizations. This study argues that it is important to understand the relationship between strategy and the use of broad scope MAS information, as this may help organizations to design appropriate MAS that provide necessary information to support their strategy for achieving competitive advantage and high performance.

Previous studies (e.g., Chong and Chong, 1997) have examined the relationship between competitive strategy and the use broad scope MAS information, using the concept of Miles and Snow's typology to define competitive strategy. However, this study follows Porter's (1980) typology, having found it to be more appropriate than Miles and Snow's typology for examining the relationship between the competitive strategy and the use of broad scope MAS information. As explained earlier in the paper that Porter's typology provides a more specific intention for a company to compete in the industry, as it explains how a company specifically positions its product in the industry as low cost or differentiation (Langfield-Smith, 1997; Kald et al., 2000). With a specific intention, an organization can identify the necessary extent of broad scope MAS information usage more specifically (see Dermer, 1977; Otley and Berry, 1980). For example a company with a cost leadership strategy can explicitly aim to be a low cost producer. It may then focus on cost monitoring; thus its managers may be required to use more financial information. However, its managers may not need to highly use broad scope MAS information such as a competitor's product features and customer preferences to monitor costs. On the other hand, to sustain a competitive advantage of differentiation, products need to be perceived by customers as having high value and being different from competitors' products. The company may focus on customer and competitor monitoring to ensure that the products meet customer expectations and are differentiated from those of competitors. Managers may then need more broad scope MAS information with respect to external and non-financial information such as a competitor's product characteristic and customer preferences. For instance, Campbell-Hunt (2000) suggested that Porter's typology has been claimed to be a dominant paradigm in management literature. This typology has been used by researchers in a wide range of applications, including diverse industries, and in diverse countries. Consistent with the literature, the present study explains competitive strategy based on the extent to which organizations employ a differentiation strategy.

Pelham and Wilson (1996) argue that to sustain the competitive advantage of product differentiation, differentiators are required to continuously improve their products (i.e. improving product quality and product features) to meet customer needs and expectations. The organizations therefore require good understanding of the customers' needs and expectations (Slater and Narver, 1996), so that they are able to offer products with greater value that can fulfil such needs and expectations (Pelham and Wilson, 1996; Narver and Slater, 1990). Broad scope MAS information, with respect to external information (such as customer preferences, expectations and satisfaction) becomes crucial for differentiators as this information can be used to determine customer needs and expectations (Mia and Clarke, 1999). For example, to sustain superiority of product quality, managers may use broad scope MAS information on customer preferences relating to product durability and reliability to identify the customers' quality expectation (Craven et al., 1998). Given that in today's competitive business environment, customer needs and expectations change rapidly (Mia and Clarke, 1999), broad scope 
MAS information relating to customer expectations and preferences becomes more useful than ever before for managers in companies with a differentiation strategy. To ensure the competitive advantage of product differentiation, managers in companies with a differentiation strategy are therefore required to use more broad scope MAS information (non-financial measures) to continuously and closely monitor how well they maintain the superior value of products. As argued by Sim and Killough (1998), without including non-financial measures (e.g. customer perceived quality, customer complaints, defect and rework) in management accounting systems, companies are unlikely to successfully provide superior quality products.

Based on the above discussion, it can be argued that the use of broad scope MAS information can assist companies adopting more of differentiation strategy to provide products that meet customer needs and expectations and are better than competitors' products; this in turn assists them to enhance their competitive advantage of differentiation. Therefore, those companies focusing more on a differentiation strategy are likely to use more broad scope MAS information. The following hypothesis formally presents the argument.

Hypothesis 2: The more a company employs a differentiation strategy, the greater is its use of broad scope MAS information.

\subsection{The Use of Broad Scope MAS Information and Financial Performance}

Managers are able to gain an understanding of external factors, particularly customers and competitors through the use of broad scope MAS information (Chenhall and Morris, 1986). Broad scope MAS information on results of customer surveys may be used by managers to understand customers' current and their future needs. They may also use external MAS information relating to a competitor's products, services, technology and strategies to analyse competitor's strengths, weaknesses and capabilities. Once managers gain such an understanding of these external factors, they may be able to respond to such factors more appropriately (Narver and Slater, 1990; Pelham, 1997). An understanding of customers' current and their future needs may assist managers to create products to meet such needs and thus appeal to customers (Dawes, 2000; Ge and Ding, 2005). So, customers may be satisfied with products and continue to purchase them (Pelham, 1997); as a result, products sales may increase (Day and Wensley, 1988; Hult and Ketchen, 2001), resulting in a greater profitability (Dawes, 2000). In addition, once managers identify a competitor's strengths, weaknesses and capabilities through the use of broad scope MAS information, they may be able to prepare for competitor's actions/activities more appropriately (Dawes, 2000). By obtaining knowledge of weakness of a competitor's products, the managers may focus on improving their own company's products to overcome the competitor's weakness. Marketing literature suggest that an understanding of strengths, weaknesses, capabilities and strategies of competitors (competitor orientation) may assist companies to improve their financial performance. Dawes (2000) reports that competitor orientation is positively associated with profitability (see also, Noble et al., 2002).

The existing literature indicates that broad scope MAS information on nonfinancial measures of production process efficiency enables managers to detect the problem within the process early (Chenhall, 1997; Mia, 2000). If the number of defective products is relatively high, managers get alerted about the problem within the production process; they then identify the problem and take corrective actions, thereby decreasing the costs related to defective products (Winata, 2005) leading to improved profits. Following the above discussion, we argue that the use of broad scope MAS information may help companies to improve their financial performance (Mia, 2000; Baines and Langfield-Smith, 2003) as presented in hypothesis three.

Hypothesis 3: The more an organization uses broad scope MAS information the greater is its financial performance.

\section{RESEARCH METHOD.}

The sample of organizations for the study was selected at random from medium to large manufacturing industries in Thailand. The list of the companies was obtained from the database of Ministry of Commerce, Thailand. Small companies were excluded since they might be reluctant to provide information about financial performance (Covin et al., 1990), which was required for the current study. According to criteria provided by the Department of Industrial Promotion, Ministry of Industry Thailand, medium to large companies must have total fixed assets of at least 20 million baht and 50 employees (Thai SMEs, 1999). Since the number of employees was not provided by the database, this study used total fixed assets to determine the size of company. In total, 470 
manufacturing companies were selected at random from the list. A questionnaire package comprising (1) a cover letter, explaining the purpose of the study and assuring anonymity of the respondents, (2) the questionnaire with a tear-off section for respondents to provide their email address or postal address for a request of the survey results, and (3) a reply-paid envelope to return the completed questionnaire was sent to the GMs of the sampled companies. Additional questionnaire packages were forwarded to those who did not receive or had misplaced the original questionnaire package as found out by follow up call. In total, 108 responses were useable (a response rate of 23.26 percent).

\subsection{Questionnaire Preparation}

Instruments used in previous studies and found to be suitable for the objectives of this study were adapted to measure the variables in the model. The adapted questionnaire package was translated from English to Thai; the professional translator then reviewed the translation of the questionnaire. Finally, following (Cooper and Schindler, 2003; and Dillman, 1978), a pilot study was conducted to enhance suitability of, and refine, the instruments in the package using feedback from the pilot study participants. The participants in the pilot study included ten academics: four in management accounting, three in marketing and three in management. The instruments were, refined using the academics' feedback (Van der Stede et al., 2005), and then reviewed. These instruments then pilot tested with six general managers in six medium to large companies. The final questionnaire package comprised the instruments that were refined using the general managers' comments. The GMs in the pilot study were not included in the final sample for data collection.

\subsection{Variable measurements}

Competitive strategy. As discussed earlier, instead of categorising strategy into either a cost leadership strategy or a differentiation strategy, the present study conceptualised competitive strategy based on the extent to which a company employs a differentiation strategy. The instrument for assessing the variable was adapted from Govindarajan (1988). It comprises five items: (1) percentage of sales spent on research and development; (2) percentage of sales spent on marketing expense; (3) product quality; (4) product features, such as shape of products and (5) brand image. A five-point Likert-type scale was used, ranging from 1 "significantly lower" to 5 "significantly higher" than leading competitors. The participants (GMs) were asked to identify the perceived position of their organizations' products relative to those of leading competitors under each of the six items in the questionnaire. The score for the competitive strategy for each GM was the average of the sum of the scores for each of the five items. A high score indicates that a company employed more of a differentiation or less of a cost leadership strategy, while a low score indicates that a company employed less of a differentiation strategy or more of a cost leadership strategy (Helm et al., 1997). The mean, standard deviation, and the minimum and maximum actual score for the construct are $3.11,0.54,1.83$, and 4.67 respectively. The standardised loadings of individual items as shown in Table 1 were between 0.67 and 0.81 , and the composite reliability of the scale was 0.85 indicating a satisfactory construct validity and reliability level (Nunnally and Bernstein, 1994; and Jermias and Gani, 2004).

The Use of Broad Scope MAS Information. To measure the use of broad scope MAS information, the instrument comprising the following items was adapted from Chenhall and Morris (1986). These items were (1) information relating to likelihood of future events occurring e.g. expected material price or expected sales volume in next year (2) noneconomic information, e.g. customer preferences, employee attitudes and competitive threats, (3) information on broad factors external to a company, e.g. economic conditions, population growth, GDP growth rate, (4) production information, e.g. output rate, scrap levels, machine efficiency, per unit production costs, (5) market information, e.g. market size, market growth. The GMs were asked to indicate (on a five-point Likert scale, ranging from 1 "not used at all" to 5) the extent to which they use information under each of the six items for their decisionmaking. The score for the use of broad scope MAS information was the average of the scores for each of the six items indicated by the managers. The mean, standard deviation, and the minimum and maximum actual score for the construct are 3.70, $0.45,2.50$, and 4.83 respectively. The standardised loadings of individual items as shown in Table 1 were between 0.56 and 0.74 , and the composite reliability of the scale was 0.78 , indicating a satisfactory construct validity and reliability level.

Organizational Performance. Financial performance in this study was defined as how well organizations achieve the financial objectives of improving profitability, increasing revenues and enhancing assets utilisations (Kaplan and Norton, 1996). The instrument was adapted from Hoque and James (2000) comprises the items: (1) sales growth; (2) operating income; and (3) return on 
investment ((Hansen and Mowen, 2000). The general managers were asked to indicate, under each of the items in the instrument, (on a five-point Likert scale ranging from (1) 'much lower' to (5) 'much higher') their organization's performance compared with the industry average. The average of these three items was taken to represent the financial performance of the managers' organizations. The mean, standard deviation, and the minimum and maximum actual score for the construct are 2.97, $0.68,1.33$, and 4.66 respectively. The standardised loadings of individual items as shown in Table 1 were between 0.73 and 0.89 , which is satisfactory and the composite reliability of the scale was 0.87 , indicating a satisfactory construct validity and reliability level

TABLE 1

VALIDITY AND RELIABILITY OF MEASUREMENTS (TOTAL SAMPLE: $\mathbf{n}=108$ )

\begin{tabular}{|c|c|c|c|c|}
\hline Indicators & $\begin{array}{l}\text { Standardized } \\
\text { Loadings }\end{array}$ & $\begin{array}{l}\text { Composite } \\
\text { Reliability }\end{array}$ & AVE & $\begin{array}{l}\text { Root } \\
\text { AVE }\end{array}$ \\
\hline Critical Values & $>.6$ & $>.7$ & $>.5$ & \multirow{5}{*}{0.726} \\
\hline S2 & 0.67 & \multirow{4}{*}{0.846} & \multirow{4}{*}{0.527} & \\
\hline S3 & 0.69 & & & \\
\hline S4 & 0.79 & & & \\
\hline $\begin{array}{l}\text { S5 } \\
\text { S6 }\end{array}$ & $\begin{array}{l}0.64 \\
0.81\end{array}$ & & & \\
\hline MAS1 & 0.70 & \multirow{5}{*}{0.782} & \multirow{5}{*}{0.420} & \multirow{5}{*}{0.648} \\
\hline MAS 2 & 0.56 & & & \\
\hline MAS 3 & 0.63 & & & \\
\hline MAS 4 & 0.59 & & & \\
\hline MAS 6 & 0.74 & & & \\
\hline $\mathrm{P} 1$ & 0.89 & \multirow{3}{*}{0.873} & \multirow{3}{*}{0.697} & \multirow{3}{*}{0.835} \\
\hline P2 & 0.88 & & & \\
\hline P3 & 0.73 & & & \\
\hline
\end{tabular}

\section{RESULTS}

Partial least square (PLS) method was used to test the hypothesised relationships between the variables that are competitive strategy, managers' use of the MAS information, and performance. The adequacy of the measurement model was assessed by examining convergent validity, discriminant validity and reliability. Table 1 presents the value for composite reliability, average variance extracted (AVE), square root of AVE for each variable, and Table 2 presents latent variable correlations and square root of AVE for each variable in the diagonal. All constructs' validity and reliability were found to be satisfactory. The composite reliability exceeds the threshold value of 0.70 , which indicates that all constructs are reliable (Hair et al., 1998; Chin, 1998; Chin et al, 2003). The AVE value above 0.50 for all constructs satisfies the test of convergent validity (Fornell and Larcker, 1981). Discriminant validity is achieved when the value of AVE for each construct should be higher than its highest squared correlation with any other construct, or the square root of AVE should be higher than its correlations (Fornell and Larcker, 1981).Once the discriminant validity of the variables are established, the next step is hypothesis testing. 
TABLE 2

SQUARED CORRELATIONS BETWEEN CONSTRUCTS (TOTAL SAMPLE: $n=108$ ) (diagonal elements represent AVE)

\begin{tabular}{|lccc|}
\hline Variable & 1 & 2 & 3 \\
\hline 1. Stragy & $\mathbf{0 . 7 2 6 ^ { \mathrm { a } }}$ & \\
2. MAS & 0.122 & $\mathbf{0 . 6 4 8}$ & \\
3. Perf. & 0.227 & 0.1160 & $\mathbf{0 . 6 9 7}$ \\
\hline & $\begin{array}{l}\text { a Bold-faced elements on the diagonal represent ROOT OF AVE. For } \\
\text { discriminant validity, the AVE in each row and column must be greater than the } \\
\text { displayed squared correlations in that row or column. }\end{array}$ \\
\hline
\end{tabular}

Figure 1 summarises the results of the PLS analysis, including the path coefficients ( $\beta$ estimates), path significance ( $p$-values), and variance explained ( $R^{2}$ values) in dependent variable. The Figure shows that the relationship between strategy and performance is positive and significant $(\beta=0.410, p<$ $0.001)$. As such, hypothesis $H_{1}$ is supported. Both hypothesised paths from strategy to MAS as well as from MAS to performance are positive and significant at the $1 \%$ level with $\beta$ equal to 0.386 and 0.196 , respectively. Thus, hypothesis 2 and 3 are supported. Strategy explains 12.2 per cent of the variance in MAS, whereas $26.2 \%$ per cent of the variance in performance is explained by both strategy and MAS. Thus it can be concluded that MAS partly mediates the relationship between strategy and performance. The result is consistent with the argument that performance of a firm will enhance as a result of the firm's adoption of the competitive strategy and its managers' use of the MAS information (Nicolaou, 2000; Haldma and Laats, 2002; Jermias and Gani, 2004; Hoque and James, 2000).

FIGURE 1

THE RELATIONSHIP BETWEEN STRATEGY, MAS INFORMATION AND PERFORMANCE

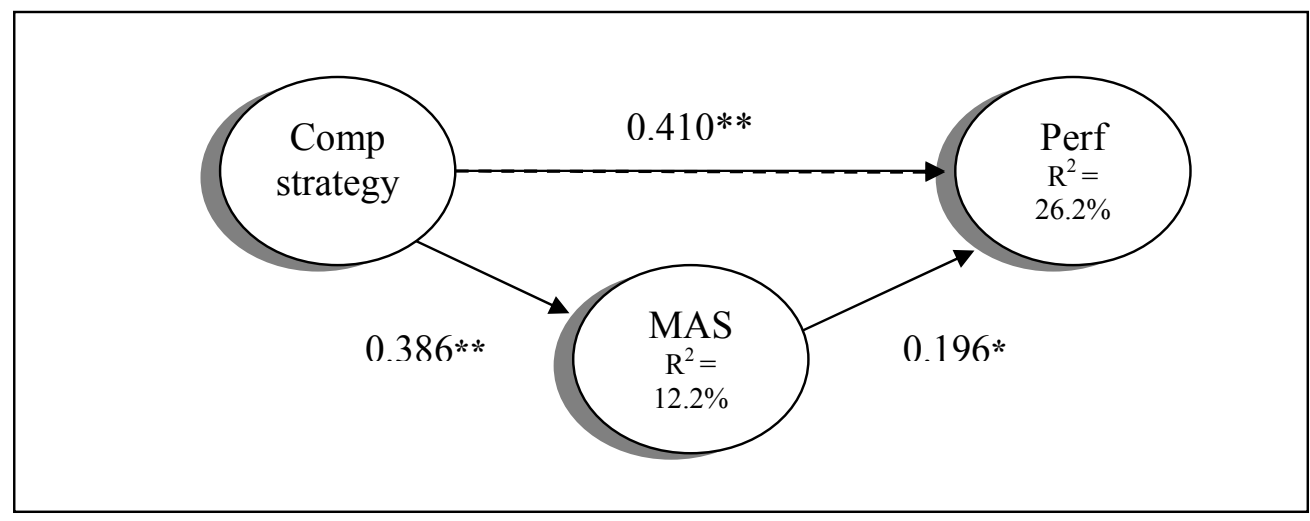

$* *$ Significant at $\mathrm{p}<0.01, *$ Significant at $\mathrm{p}<0.05$

\section{DISCUSSION AND CONCLUSION}

This study investigated the association of competitive strategy and company performance and also the role of managerial use of the MAS information in the relationship between companies' competitive strategy and performance. The results revealed that while an organization's competitive strategy is directly and positively associated with its financial performance, the association is also indirect via managerial use of the MAS information. The total sample, the direct and indirect association together explains $26.20 \%$ of variance in performance while the competitive strategy alone (i.e., the direct relationship) explains $22.64 \%$ of the variation in the performance. Therefore, the incremental explanation of variance in performance due to inclusion of MAS in the analysis is $3.54 \%(26.20 \%-$ 
22.66\%) which is substantive. In other words, both the direct and indirect relationships were important.

There are two limitations to the study that are important to be pointed out. First, the sample comprising 108 organizations from different manufacturing industries is rather small. Therefore, generalisation of the results requires cautions. Second, the results could vary from industry to industry. As our sample included various industries and the number of participating companies even by major group of industries was small, more detailed analysis of the results could not be undertaken. We believe future studies can significantly contribute to existing knowledge in this area by conducting similar studies in specific industry.

Notwithstanding the limitations, this study contributes to the current knowledge in this area. Relevant previous research concentrated on Miles and now's strategy typology to operationalise competitive strategy. This study is different from those prior studies as it focused on Porter's typology to operationalise competitive strategy, thereby explains the inconclusive results reported in relevant previous studies.

\section{Author Profile:}

Dr. Lokman Mia earned his PhD at University of Queensland, Australia in 1985. Currently he is Professor of Accounting at Griffith University, Queensland, Australia. Dr Mia published in Decision Sciences; Accounting, organizations and Society; Accounting, Auditing and Accountability Journal, British Accounting Review; Accounting and Business Research, Financial Accounting and management; International Journal of Hospitality Management; Journal of Hospitality and Tourism Research.

Dr Sirilak Bangchokdee earned her PhD at Griffith University, Queensland, Australia in 2008. Dr. Bangchokdee is currently Associate Dean in the School of Business, Prince of Sonkla University, Thailand.

\section{REFERENCES:}

Abernethy, M. A., and Guthrie, C. H. (1994). An empirical assessment of the "fit" between strategy and management information system design. Accounting and Finance, 34(2), 49-66

Abernethy, M. A., and Lillis, A. M. (1998). Complementarities in control system design: a test in hospitals. Paper presented at the University of New South Wales Sixth Biennial Management Accounting Research Conference

Anderson, E. W., Fornell, C., and Lehmann, D. R. (1994). Customer satisfaction, market share, and profitability: findings from Sweden. Journal of Marketing, 58(3), 53-66.

Anderson, E. W., and Sullivan, M. W. (1993). The antecedents and consequences of customer satisfaction for firms. Marketing Science (1986-1998), 12(2), 125.

Anderson, T. J. (2004). Integrating decentralized strategy making and strategic planning process in dynamic environments. Journal of Management Studies, 41(8), 1271-1299.

Baines, A., and Langfield-Smith, K. (2003). Antecedents to management accounting change: a structural equation approach. Accounting Organizations and Society, 28, 675-698.

Bank of Thailand. (2007a). Manufacturing production index by product group. Retrieved 6 May, 2007, from Http://www.bot.or.th/BOTHomepate/Library

Campbell-Hunt, C. (2000). What have we learned about generic competitive strategy? a metaanalysis. Strategic Management Journal, 21(2), 127.

Carmeli, A., and Tishler, A. (2005). Perceived organizational reputation and organizational performance: an empirical investigation of industrial enterprises. Corporate Reputation Review, 8(1), 13.

Chenhall, R. H. (1997). Reliance on manufacturing performance measures, total quality management and organizational performance. Management Accounting Research, 8, 187-206.

Chenhall, R. H., and Morris, D. (1986). The impact of structure, environment, and interdependence on the perceived usefulness of management accounting systems. The Accounting Review, $L X I(1), 16-35$.

Chenhall, R. H., and Langfield-Smith, K. (1998). The relationship between strategic priorities, management techniques and management accounting: an empirical investigation using a systems approach. Accounting Organizations and Society, 23(3), 243-264.

Chin, W.W. (1998). 'The partial least square approach to structural equation modeling', in: Marcoulides, G.A. (ed.), Modern Methods for Business Research. Mahwah: Lawrence Erlbaum: 295-336. 
Chin, W.W., Marcolin, B.L. and Newsted, P.R. (2003). 'A partial least squares latent variable modeling approach for measuring interaction effects: results from a Monte Carlo simulation study and voice mail emotion / adoption study'. Information Systems Research, 14: 189-217.

Chong, V. K., and Chong, K. M. (1997). Strategic choices, environmental uncertainty and SBU performance: a note on the intervening role of management accounting systems. Accounting and Business Research, 27(4), 268-276

Cooper, D. R., and Schindler, P. S. (2003). Business research methods (8th ed.). Boston: McGrawHill/Irwin.

Covin, J. G., Prescott, J. E., and Slevin, D. P. (1990). The effects of technological sophistication on strategic profiles, structure and firm performance. The Journal of Management Studies, 27(5), 485-511.

Cravens, D. W., Holland, C. W., Lamb, C. W., and Moncrief, W. C. (1988). Marketing's role in product and service quality. Industrial Marketing Management, 17, 285-304.

Dawes, J. (2000). Market orientation and company profitability: further evidence incorporating longitudinal data. Australian Journal of Management, 25(2), 173-199.

Dent, J. F. (1990). Strategy, organization and control: some possibilities for accounting research. Accounting, Organizations and Society, 15(1/2), 3-25.

Dess, G. G., and Davis, P. S. (1984). Porter's (1980) generic strategies as determinant of strategic group membership and organizational performance. Academy of Management Journal, 27(3), 467-488.

Dermer, J. (1977). Management planning and control systems: Irwin.

Devaraj, S., Matta, K. F., and Conlon, E. (2001). Product and service quality: the antecedents of customer loyalty in the automotive industry. Production and Operations Management, 10(4), 424.

Dillman, D. A. (1978). Mail and telephone surveys. New York: A Wiley-Interscience Publication.

Fornell, C, and Larcker, D.F. (1981). Evaluating structural equation models with unobservable variables and measurement error, Journal of Marketing Research, 18, pp. 39-50.

Ge, G. L., and Ding, D. Z. (2005). Market orientation, competitive strategy, and firm performance: an empirical study of Chinese firms. Journal of Global Marketing, 18(3/4), 115-141.

Gordon, L. A., and Narayanan, V. K. (1984). Management accounting systems, perceived environmental uncertainty and organization structure: an empirical investigation. Accounting, Organizations and Society, 9(1), 33-47.

Govindarajan, V. (1988). A contingency approach to strategy implementation at the business-unit level: integrating administrative mechanisms with strategy. Academy of Management Journal, 31(4), 828-853.

Gul, F. A., and Chia, Y. M. (1994). The effects of management accounting systems, perceived environmental uncertainty and decentralization on managerial performance: A test of threeway interaction. Accounting Organizations and Society, 19, 413-426.

Hambrick, D. C. (1983). High profit strategies in mature capital goods industries: a contingency approach. Academy of Management Journal, 26, 687-707.

Helms, M. M., Dibrell, C., and Wright, P. (1997). Competitive strategies and business performance: evidence from adhesives and sealants industry. Management Decision, 35(9), 689.

Hoque, Z., and James, W. (2000). Linking balanced scorecard measures to size and market factors: impact on organizational performance. Journal of Management Accounting Research, 12, 117.

Hoque, Z. (2003). Strategic management accounting (2 ed.). London: Spiro Press.

Hult, T. M., and Ketchen, D., J. Jr. (2001). Does market orientation matter? a test of the relationship between positional advantage and performance. Strategic Management Journal, 22(9), 899.

Jermias, J., and Gani, L. (2004). Integrating business strategy, organisational configurations and management accounting systems with business unit effectiveness: a fitness landscape approach. Management Accounting Research, 15, 179-200.

Kald, M., Nilsson, F., and Rapp, B. (2000). On strategy and management control: the importance of classifying the strategy of the business. British Journal of Management, 11(3), 197-212.

Kaplan, R. S., and Norton, D. P. (1996a). The balanced scorecard: translating strategy into action. Boston: Harvard Business School Press.

Kotler, P. (2003). Marketing management (11th ed.). Upper Saddle River, N.J.: Prentice Hall.

Langfield-Smith, K. (1997). Management control systems and strategy: a critical review. Accounting, Organizations and Society, 22(2), 207-232.

Miles, R. E., and Snow, C. C. (1978). Organizational strategy, structure, and process. New York: McGraw-Hill.

Mia, L., and Clarke, B. (1999). Market competition, management accounting systems and business unit performance. Management Accounting Research, 10, 137-158. 
Mia, L. (2000). Just-in-time manufacturing, management accounting systems and profitability. Accounting and Business Research, 30(2), 137-151.

Mia, L. (1993). The role of MAS information in organisations: an empirical study. British Accounting Review, 25, 269-285.

Mosakowski, E. (1993). A resource-based perspective on the dynamic strategy-performance relationship: an empirical examination of the focus and differentiation strategies in entrepreneurial firms. Journal of Management, 19(4), 819-839.

Nunnally, J. C., and Bernstein, I. H. (1994). Psychometric theory (3 ed.). New York: McGraw-Hill, INC.

Olson, E. M., and Slater, S. F. (2002). The balanced scorecard, competitive strategy, and performance. Business Horizons, 45(3), 11-16.

Otley, D. T. (1980). The contingency theory of management accounting achievement and prognosis. Accounting, Organizations and Society, 5(4), 413-428.

Otley, D. T., and Berry, A. J. (1980). Control, organisation and accounting. Accounting Organizations and Society, 5(2), 231.

Patiar, A. K. (2005). Managers' perception of market competition, transformational leadership, use of MAS information and performance: a cross-cultural study in hotels. Griffith University, Gold Coast, Queensland.

Porter, M. E. (1980). Competitive strategy. New York: The Free Press.

Porter, M. E. (1985). Competitive Advantage. New York: Free Press.

Sands, J. S. (2006). Strategic priorities, management control systems, and managerial performance: an empirical study. Griffith University, Queensland.

Simons, R. (1987). Accounting control systems and business strategy: an empirical analysis. Accounting, Organizations and Society, 12(4), 357-374.

Simons, R. (1990). The role of management control systems in creating competitive advantage: new perspectives. Accounting, Organizations and Society, 15(1/2), 127-143.

Slater, S. F., and Narver, J. C. (1996). Competitive strategy in the market-focused business. Journal of Market Focused Management, 1(1), 159-174.

Tsiotsou, R. (2006). The role of perceived product quality and overall satisfaction on purchase intentions. International Journal of Consumer Studies, 30(2), 207.

Van der Stede, W. A., Young, S. M., and Chen, C. X. (2005). Assessing the quality of evidence in empirical management research: The case of survey studies. Accounting, Organizations and Society.

Winata, L. R. (2005). Manufacturing automation, strategic alliance, information technology and organisational performance: evidence from Indonesia. Griffith University, Gold Coast.

Yamin, S., Gunasekaran, A., and Mavondo, F. T. (1999). Relationship between generic strategies, competitive advantage and organisational performance: an empirical analysis. Technovation, $19,507-518$. 
Copyright of International Journal of Business Research is the property of International Journal of Business Research and its content may not be copied or emailed to multiple sites or posted to a listserv without the copyright holder's express written permission. However, users may print, download, or email articles for individual use. 